\title{
Research Paper \\ Analyzing the Attitudes of the Experts to Compare the Advantages and Disadvantages of Rural Child Labor in Agricultural Activities
}

\author{
Ali Asghar Mirakzadeh ${ }^{1}$, Kiumars Zarafshani ${ }^{2},{ }^{*}$ Faranak Karamian ${ }^{3}$
}

1. Assistant Professor, Department of Agricultural Extension and Education, Faculty of Agriculture, Campus of Agriculture and Natural Resources, Razi University Kermanshah, Iran

2. Associate Professor, Department of Agricultural Extension and Education, Faculty of Agriculture, Campus of Agriculture and Natural Resources, Razi University, Kermanshah, Iran.

3. PhD Candidate, Department of Agricultural Extension and Education, Faculty of Agriculture, Campus of Agriculture and Natural Resources, Razi University, Kermanshah, Iran.

$\begin{aligned} & \text { Use your device to scan } \\ & \text { and read the article online }\end{aligned}$
dhe Advantages and Disadvantages of Rural Child Labor in Agricultural Activities (Persian)]. Journal of Rural Research, 8(1),
68-81. http://dx.doi.org/10.21859/jjr-08015

Received: 09 Oct. 2016 Accepted: 21 Dec. 2016

Key words:

Children, Atti-

tudes, Child labor,

Q-methodology,

Agriculture

\begin{abstract}
A B S T R A C T
With regard to the role of children in agricultural activities, the current study aimed at analyzing the attitudes of experts towards the advantages and disadvantages of rural child labor in agricultural activities. The study was conducted by Q-methodology; The study population included the experts of Sayed Yaqub Health Center of Mahidasht County, Iran, and the staff of Charity Committee of Kermanshah County. Totally, 16 experts were selected by the purposeful sampling method. Results showed that the first group believed that children labor deprives the children from childhood activities. The other group believed that child labor lessens the focus of children in the class; on the other hand, strengthens the culture of the region. The third group believed that agricultural activities are among the factors that cause responsibility in children. The fourth group believed that child labor, due to the independence of children, causes joint diseases. The fifth group had a different viewpoint about child labor; they believed that child labor makes the child more agile from the physical point of view, but causes emotional depression. It can be said that the child labor phenomenon in rural areas is associated with the nature of pastoralism. Child labor contributes to economic affairs, households, and family by cultural truism rural residents. But in Iran can be the valve kind of transfer, age of onset, the quantity and quality of work and children's rights into action.
\end{abstract}

\section{Extended Abstract}

\section{Introduction}

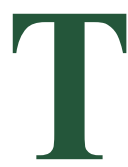

he role and status of villages in economy is undeniable. Most people in the villages live on agriculture that can guarantee food security, employment, and livelihoods in rural areas. Child labor in agriculture is prevalent in both developing and developed countries. Child laborers are at risk of a wide variety of machinery, biological, physical, chemical, dust, ergonomic, welfare/hygiene, and psychosocial dangers. However, children are not always in danger when doing agriculture. On the contrary, some experiences are rewarding, providing children with practical and social skills like adults. Higher self-confidence, self-esteem, and work skills are usually seen in young people engaged in farm work. Such work can contribute both to children's

\section{* Corresponding Author:}

\section{Faranak Karamian, PhD Candidate}

Address: Department of Extension and Rural Development, Faculty of Agriculture, Campus of Agriculture and Natural Resources, Razi University, Imam Khomeini Highway, Kermanshah, Iran.

Tel: +98 (918) 5832204

E-mail: karamyan.f@gmail.com 
development and the welfare of their families; it will prepare children to be resourceful members of society.

\section{Methodology}

The current study used the Q-methodology to classify the perceptions of experts of Sayed Yaqub Health Center in Mahidasht County, Iran, and the staff of Charity Committee of Kermanshah toward the advantages and disadvantages of rural child labor in agricultural activities. The Q-methodology provides a systematic study of subjectivity, person's viewpoint, opinions, beliefs, attitude, and so on. Typically, in Q-methodological study, the subjects are presented with a sample of statements about some topics, called the Q-set. Respondents, the P-set, should rankorder the statements from their individual's point of view, based on some preferences, judgments, or feelings, mostly using a quasi-normal distribution. By Q-sorting, the subjects give their subjective meaning to the statements, and consequently reveal their subjective viewpoint or personal profile. Q participants are the people with clearly different beliefs asked to express beliefs about the Q statements by categorization them; ie, "doing a Q-sort.” Naturally, a few dozens of Q-sorts are placid.

They are analyzed using statistical techniques of correlation and factor analysis to disclose outlines in the way people subordinate beliefs. The consequences of the examination are construed and articulated as dissimilar public standpoints. A Q-study also indicated the way the persons who did the Q-sort approve or distress with the standpoints. In this context, using literature review and interviewing 16 experts of Sayed Yaqub Health Center and the staff of Charity Committee of Kermanshah, 122 statements were identified. Then, by removing one word statements and prioritizing them by the experts, 30 final statements or the so called Q-samples remained. Subsequently, SPSS version 18 software was used to analyze the data.

\section{Results}

Results showed that the first group believed that child labor takes the opportunity of enjoying the childhood from the children. The other group believed that the child labor takes the concentration of the children in the class; on the other hand, is strengthened the culture of the region; while the third group believed that children working in the agricultural activities would be responsible for children in the future. The fourth group believed that child labor causes independence in children and on the other hands, causes the joint diseases. The fifth group had a different view about child labor; they believed that child labor makes children more agile, from the physical point of view, but emotionally, causes depression in them.

\section{Discussion}

The first paradigm: Overall, it can be inferred that as the disadvantages of child labor are greater than its advantages; therefore, its benefits can be overlooked. According to the second group, child labor transfers and strengthens the culture of the village, but the fact that child labor affects children's education is very important and should be considered. Generally, the third group mentality disagreed with the negative effects of mental and physical child labor, despite causing the exhaustion and lack of focus in the classroom. The fourth group, unlike the third group, believed that child labor caused joint diseases, but disagreed with the viewpoint that it caused mental illnesses. It can be said that the fifth group did not have negative feelings about child labor. They considered the agility and independence of children, which can affect their future, as important issues.

\section{Conclusion}

Although the advantages, disadvantages, and the general phenomenon of child labor can be common global and regional challenges in a global perspective, the cultural phenomenon is analyzed at the level of regional and local economy. Culture in general can be derived from past history, ideology, geographical, and climatic conditions, political decisions, and security; therefore, the cultural diversity in the field is also visible. There is a multi-dimensional issue of child labor in particular the decision-making and planning in this regard need to be worked on global, regional, and local joint institutional cooperation. It is recommended that the health centers, and welfare, and the children's rights supporting organizations provide the parents and children the required training and make the parents aware of the disadvantages of child labor. Due to the physical and emotional problems that children faced in agricultural work; it is recommended to promote the culture of child abuse prevention, and train the children properly on how to properly prevent further work-related injuries. Since children also work in the short-term to increase the family income, but in the long-term it has negative effects on the economy of the society, it is recommended that organizations such as the Relief and Welfare Committee, Iran, with the support of the families of the children prevent from putting too much pressure on children. 


\section{Acknowledgments}

This research was extracted from the MA thesis of the third author, Department of Agricultural Extension and Education, Faculty of Agriculture, Campus of Agriculture and Natural Resources, Razi University, Kermanshah, Iran.

\section{Conflict of Interest}

The authors declared no conflicts of interest. 


\title{
تحليل نتَرش كارشناسان دربرابر مزايا و معايب كار كودكان روستايى در فعاليتهاى كشاورزى
}

\author{
على اصغر ميركزاده'، كيومرث زرافشانى'، "فرانك كرميان” \\ ا- استاديار، كروه ترويج و آموزش كشاورزى، دانشكده كشاوزي، يرديس كشاورزى و منابع طبيعى، دانشكاه رازى، كرمائشاه، ايران.

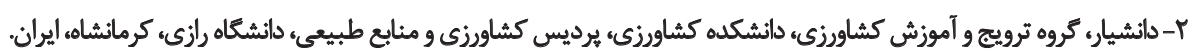

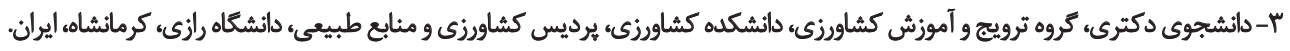

\begin{abstract}
حكبد

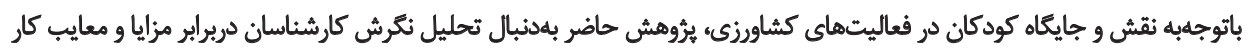

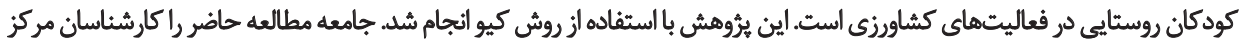

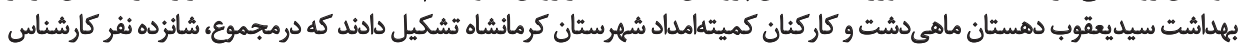

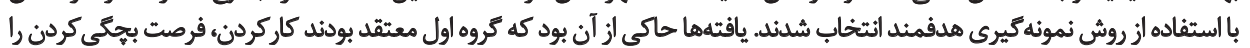

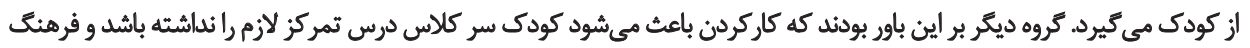

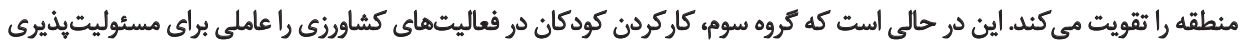

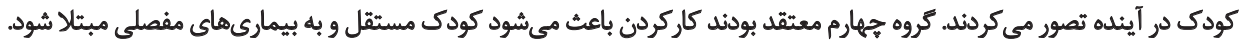

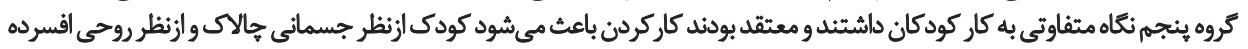

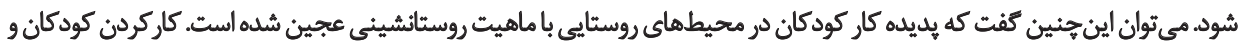

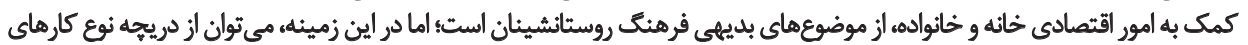

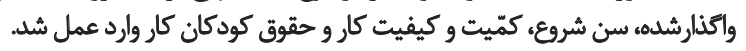

تاريخ دريافت: $1 A$ مهر هوش

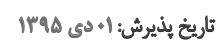

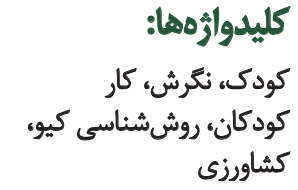

كليدوارٔهها:

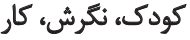

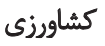

جهان گزارش كرد كه بخش بزركى از آن را كودكان (درحدود

مقدمه

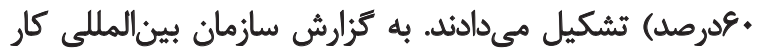

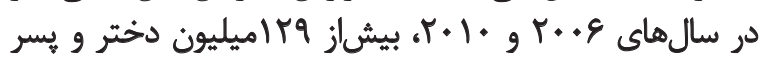

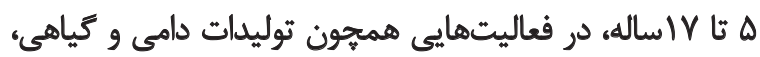

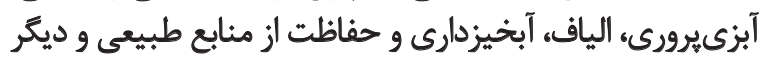

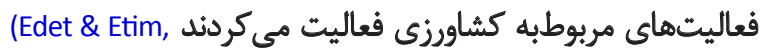

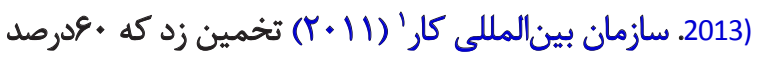

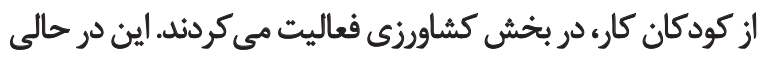

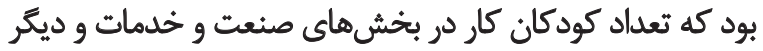

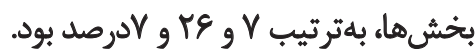

آمارهاى مختلفى وجود دارد كه نشان مي دهد تعداد كاركران

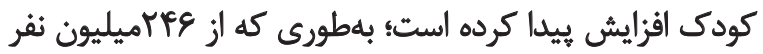

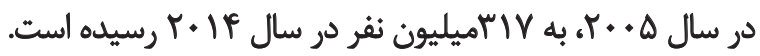

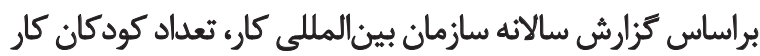

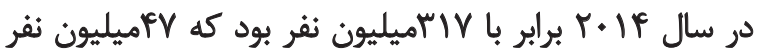

1. International Labor Organization

نقش و جايكاه روستاها در فرايند توسعه اقتصادى، اجتماعي،

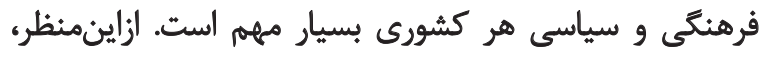

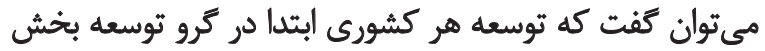

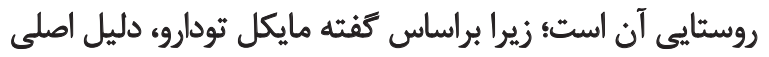

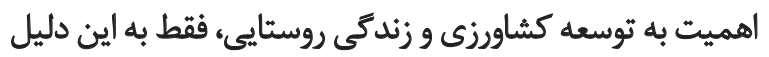

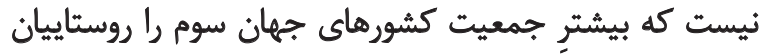

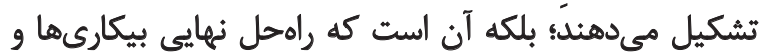

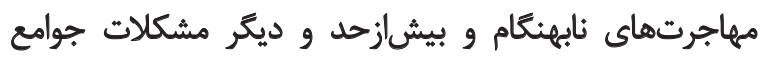

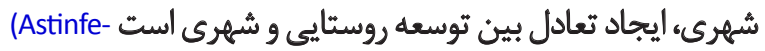
shan, Alibaygi, Gholami, 2012).

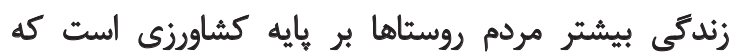

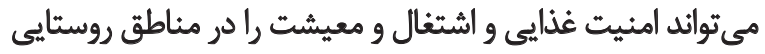
تضمين كند (International Labor Organization, 2011). در سال رال

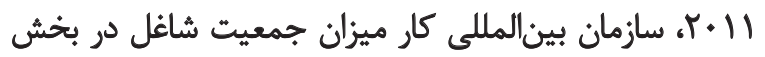

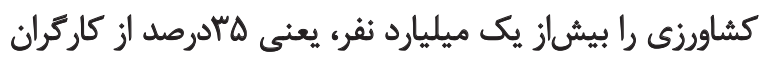

\section{-}

: فريسئده مسئول:

فرانك كرميان

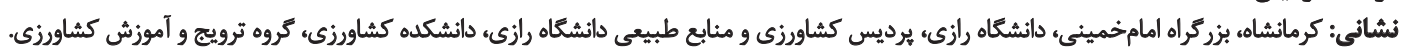

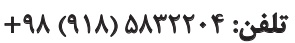
يست الكترونيكي: karamyan.f@gmail.com 
بررسى نكَرش كارشناسان و مسئولان دربرابر مزايا و معايب كار

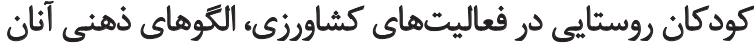
با بهرهيرى از روش كيو استخراج شود.

\section{مرورى بر ادبياث موضوع}

صندوق كودكان ملل متحد (يونيسف) (F) • (Y)، دوران كودكى

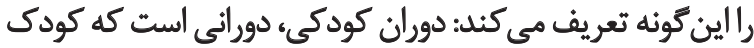

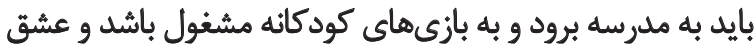

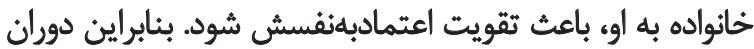

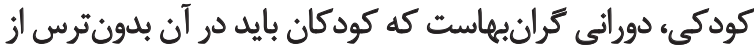

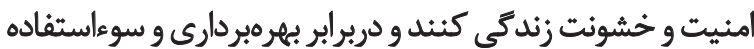

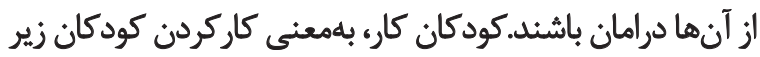

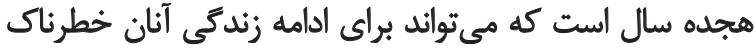

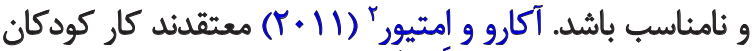

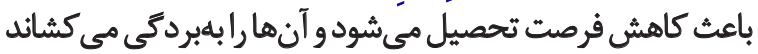

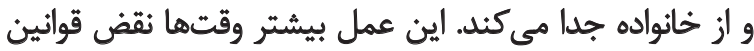
بينالمللى و ملى حقوق كودكان محسوب مي كمشود.

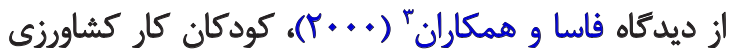

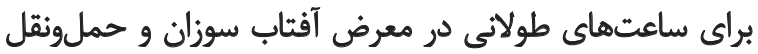

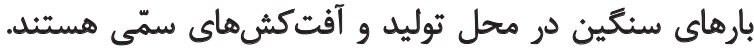

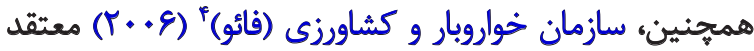

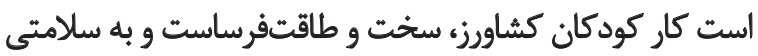

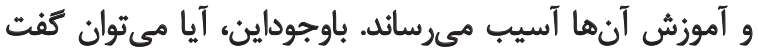

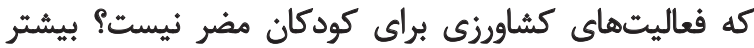

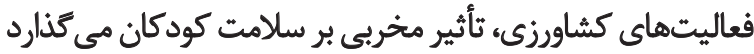

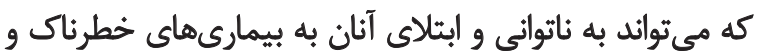

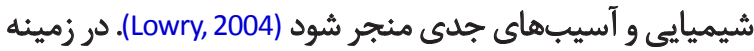

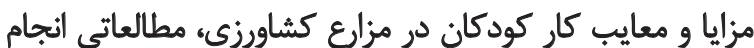

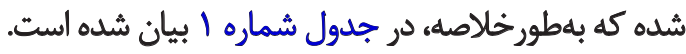

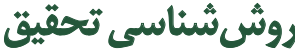

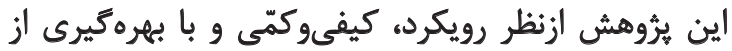

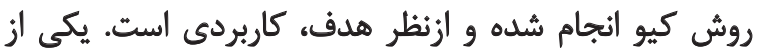

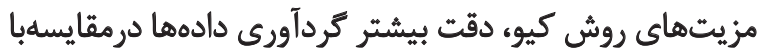

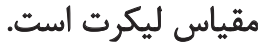

جامعه و نمونه آمارى اين يثروهش، كارشناسان مركز بهداشت

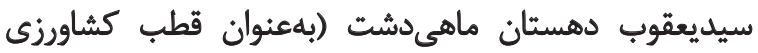

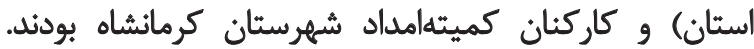

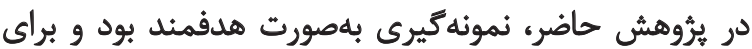

2. Akarro \& Mtwere

3. Fassa et al.

4. Food and Agriculture Organization (FAO)

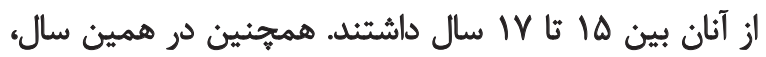

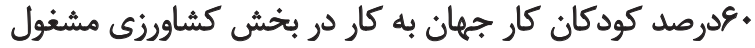
بودند (International Labor Organization, 2015).

كار كودكان، موضوع مهام جهائى است كه درنتيجه فقرء رشد

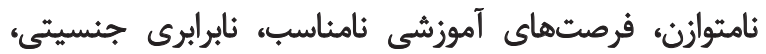

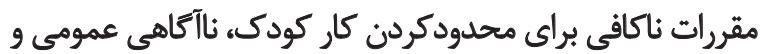
طيف وسيعى از خطر بهداشتى ايجاد مي مشودود (Forastieri, 2002).

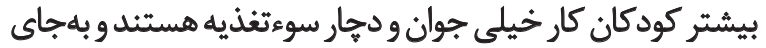

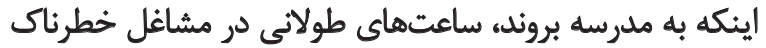

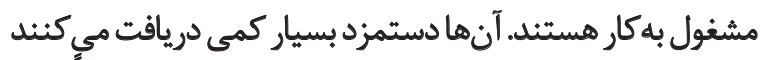

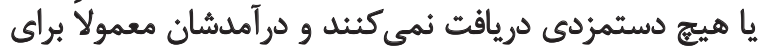

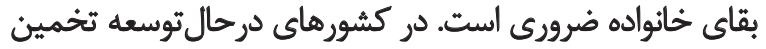

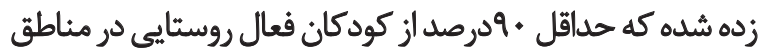
روستايى، در بخش كشاورزى فعاليت مى كنيند (Wilk, 1993). كار كودكان در هر نقطه از جهان ديده مى بودو؛ اما اين يديده

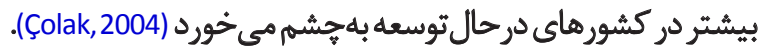

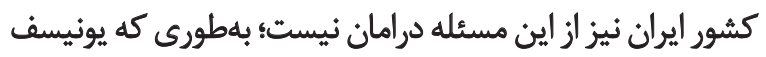

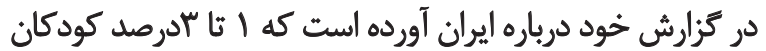

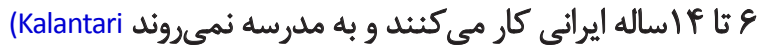

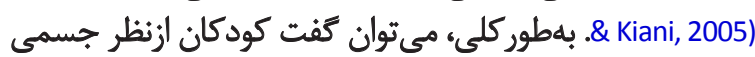

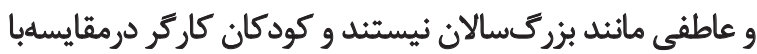

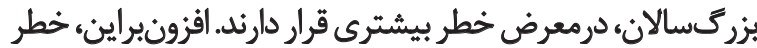

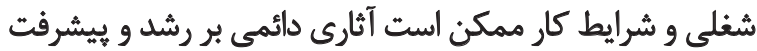
كودكان كار داشته باشد (Forastieri, 2002).

كشاورزى از مههمترين بخشهاى اقتصادى كشور است و نقش

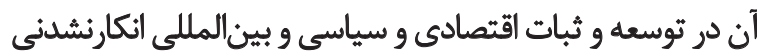

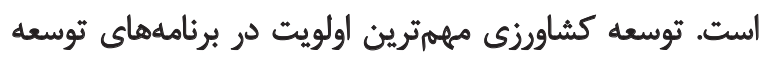

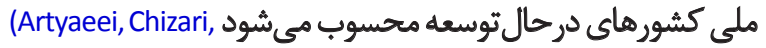

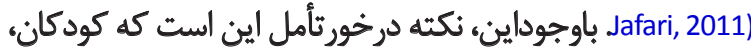

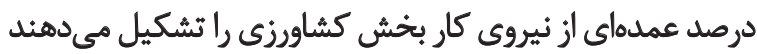

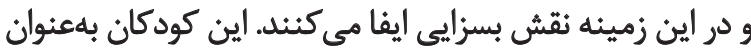

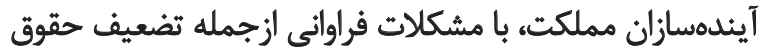

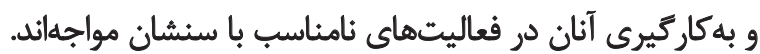

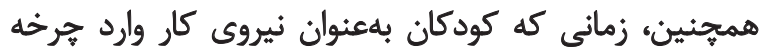

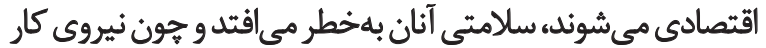

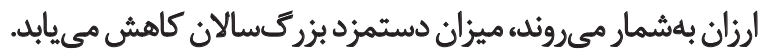

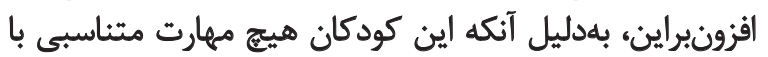

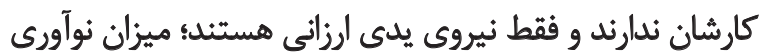

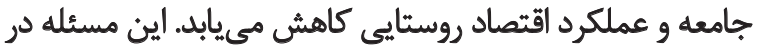

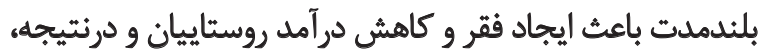
مانع توسعه روستايى مىشود. برايناساس، هدف از انجام يُروهش حاضر اين بود كه ضمن 
جدول ا. مطالعات انجامشده در زميئه مزايا و معايب كار كودكان در فعاليتهاى كشاورزى

\begin{tabular}{|c|c|c|}
\hline نام نويسنده و سال ئورهش & كشور مطالعهشده & 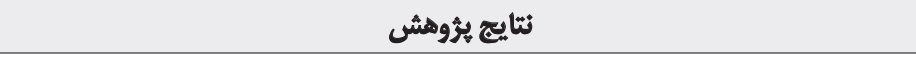 \\
\hline Banerjee (1993) & غرب بئكال & كودكانى كه در مزارع كار مى كنند، دجار كمخونى و عفونت دستكاه ثنفسى و جشم و بيمارى هاى \\
\hline National Research Council & & كاركردن باعث توسعه نظم و انضباط، مسئوليتيذيرى، اعتمادبهنفس، استقال و أموزش به \\
\hline $\begin{array}{c}\text { (1998) } \\
\text { Cruz (2002) }\end{array}$ & هندوراس & 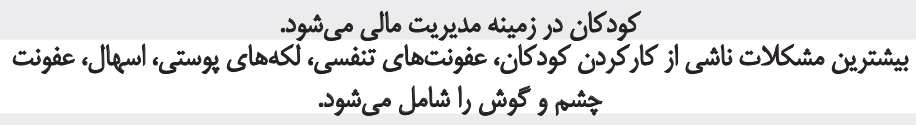 \\
\hline Rosati \& Straub (2004) & كواتمالا & انجام كار در كودكى، احتمال وقوع بيمارى در بزرىسالى را بلميزان +Fادرصد اقزايش هىدهل. \\
\hline $\begin{array}{l}\text { Heady (2003); Leinberger et } \\
\text { al. (2005) }\end{array}$ & & كودكان كار بهدليل خستلبودن و تمركزنداشتن، بعد أز مدتى مدرسه را رها مى كنئد. \\
\hline Mull \& Kirkhorn (2005) & غنا & 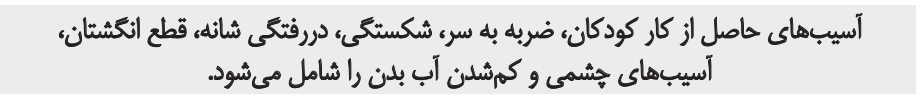 \\
\hline Gamlin et al. (2006) & مكزيك & 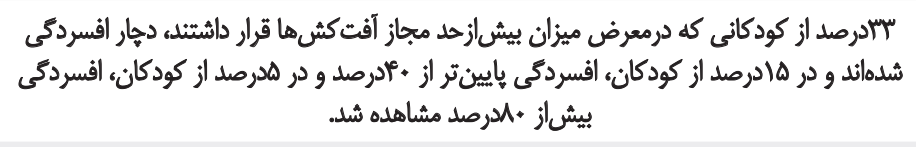 \\
\hline $\begin{array}{l}\text { International Labor Organiza- } \\
\text { tion and International Pro- } \\
\text { gramme on the Elimination of } \\
\text { Child Labour (2007) }\end{array}$ & & 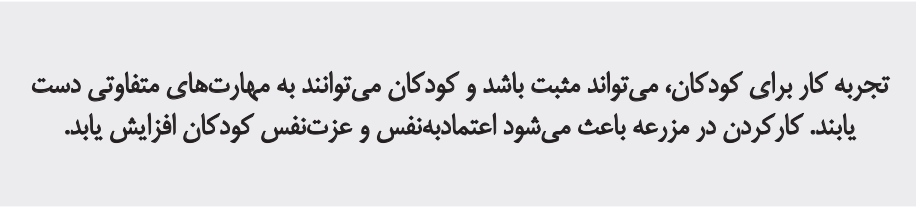 \\
\hline Kotb et al. (2011) & مصر & 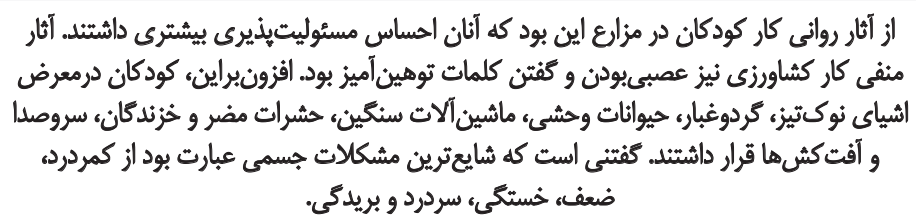 \\
\hline
\end{tabular}

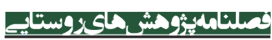

موضوع تحقيق بررسي و سيس ازطريق مصاحبه با اهالي كُفتمان،

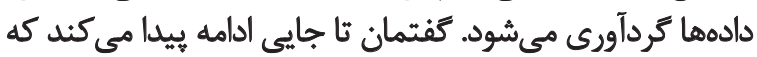

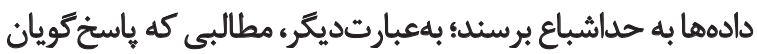

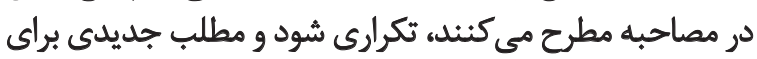

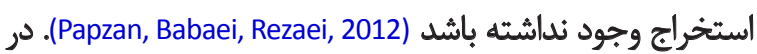

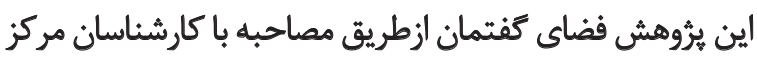

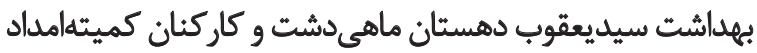

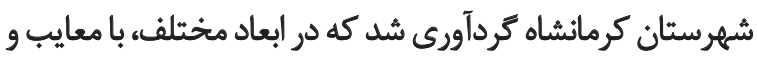
مزاياي كاركردن كودكان مرتبط بودند.

$$
\text { نمونه كيو" }
$$

در اين مرحله، مطالب بلدستآمده از بررسى منابع اسنادى

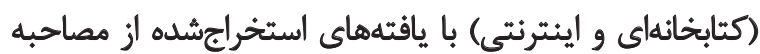

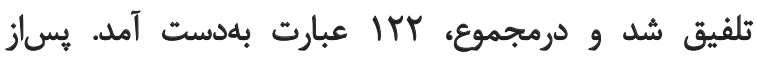
جمعبئدى و حذف عبارات ثكرارى، نمونه كيو در قالب سي كزار شكل كرفت كه معرّف فضاى كثتمان بودي

6. Q-sample
كردآورى اطلاعات از افراد مهمه و مطلع استفاده شد. برخلاف

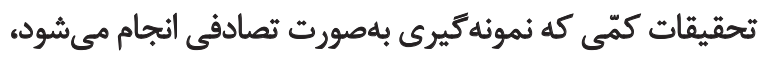

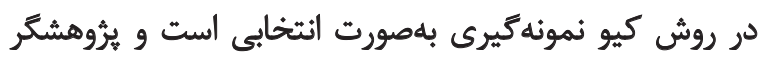

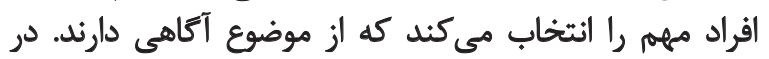

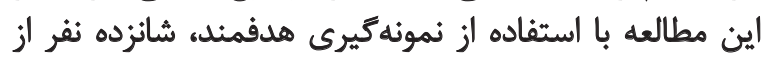

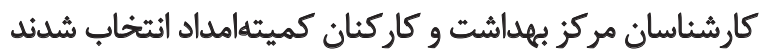
كه بهطورمستقيم با كودكان درارتباط بودنئ. روشي كيو هم شيوه كرد آورى دادهها (مرتبسازى كيو) و هم

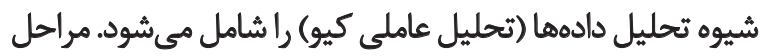
اجراى روش كيو بلصورت زير است:

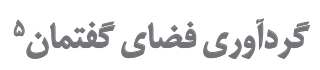

فضاى كُفتمان، شامل مجموعلاي از مطالب متنّع و متعدد

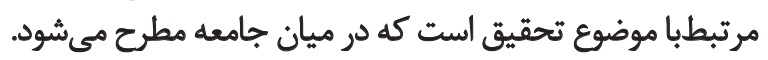

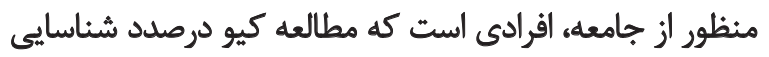

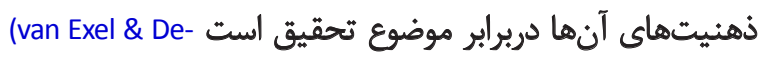
Graaf, 2005)

\section{Concourse}


جدول r. كزارههاي مربوطبه تحليل نكرش كارشناسان دربرابر مزايا و معايب كار كودكان روستايى در فعاليتهاي كشاورزى

كاركردن باعث مى شود كودكان خسته شونل و سر كلاس درس تمركز لازم رانداشته باشند.

كاركردن باعث هي شود در اعصاب كودكان اختلال بلوجود آيد و آنان كلمات توهين آميز بهكار برند.

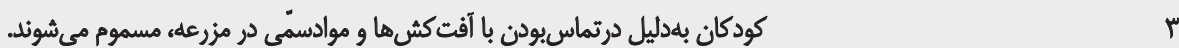

كاركردن باعث مي شود كودكان درآيثله به سوءنغذيه دهار شونلد.

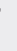

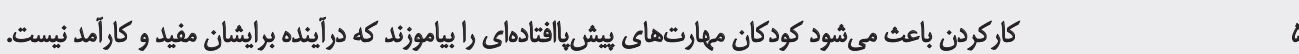

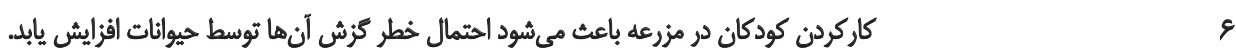

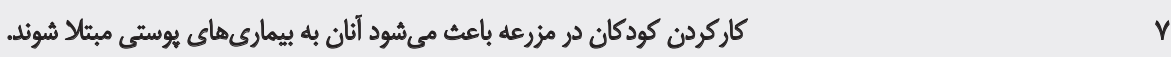

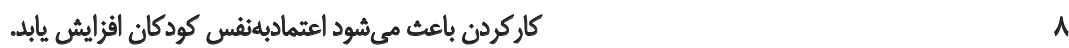

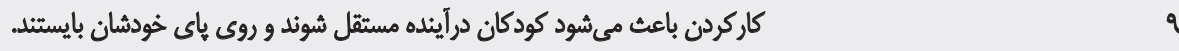

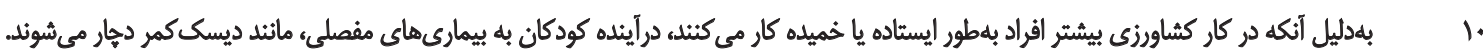

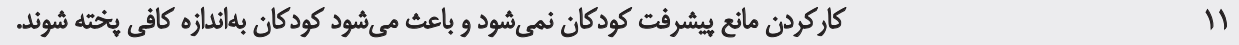

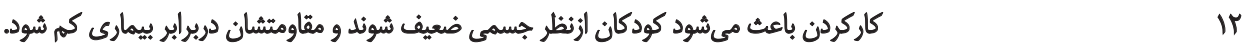

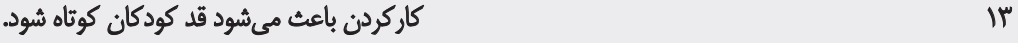

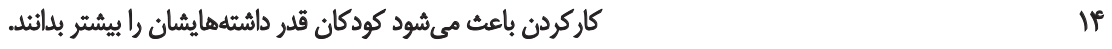

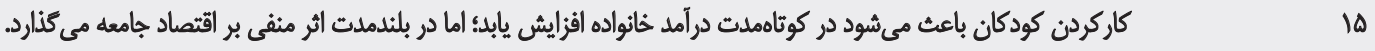

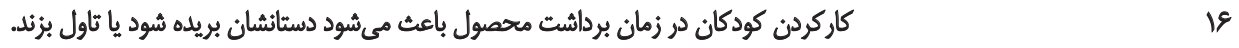

كاركردن از شكوفايى استعدادهاى كودكان، بلهوئه در زميئه تحصيلى و ورزش، جلوكيرى مى كند.

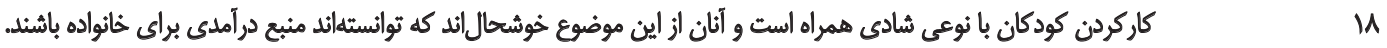

19

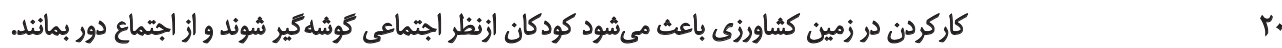

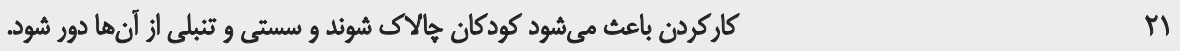

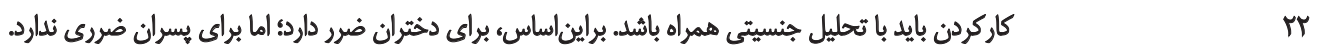

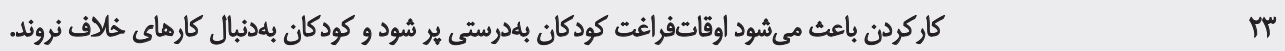

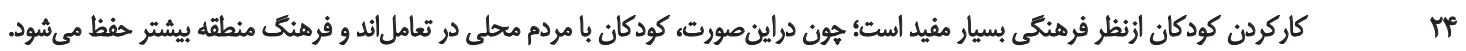

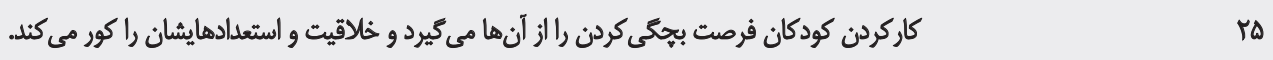

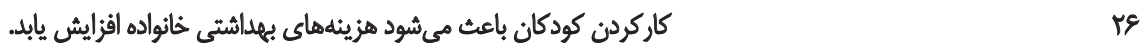

كاركردن باعث مى شود كودكان ازنظر تحصيلى افت كنند و هزينههاى أموزشى افزايش يابل.

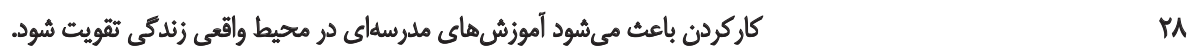

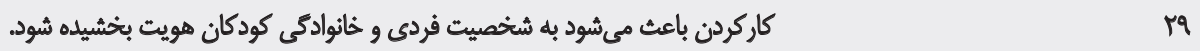

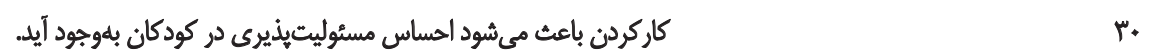


تصوير ا. شيوه مرثبسازى تويهها به روش اجبارى

كاملاً مخالفم كاهياً موافققم

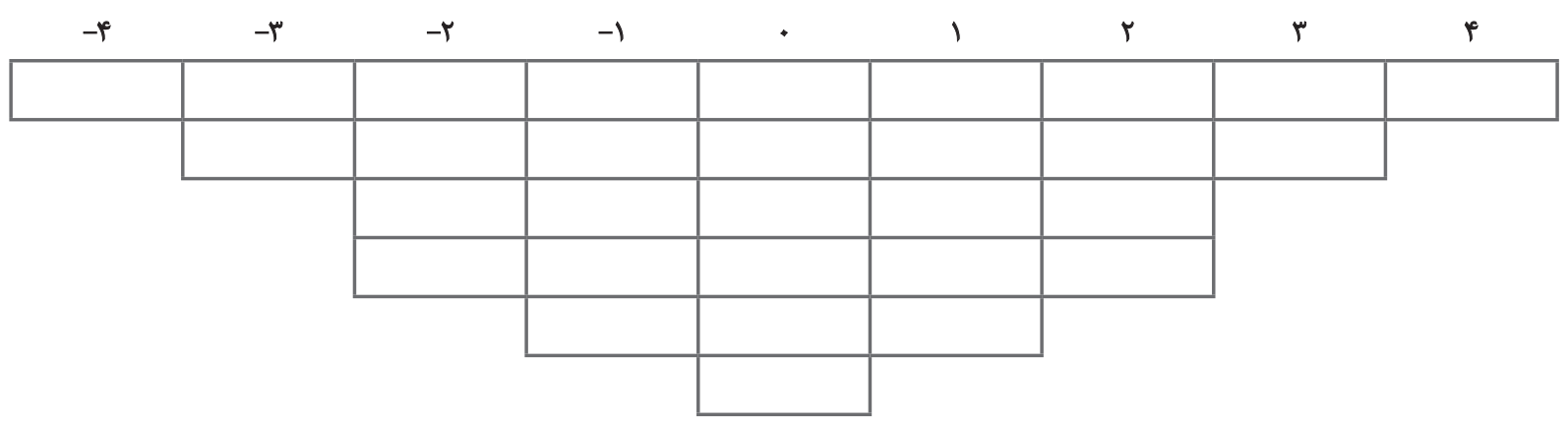

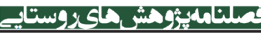

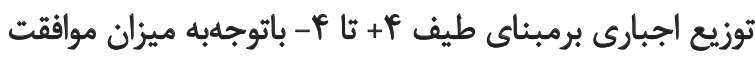

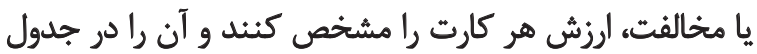

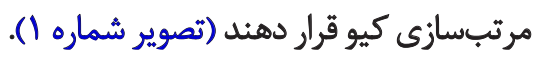

كفتنى است كه ضمن گردآورى دادهها و تكميل جدول (تصوير

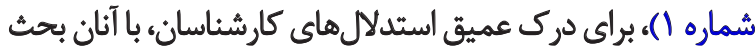

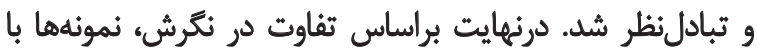

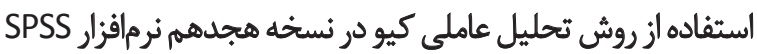

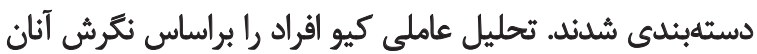

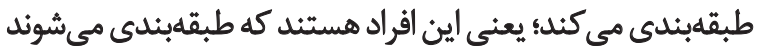

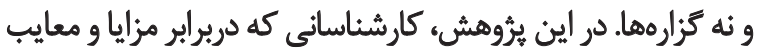

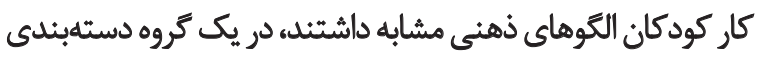

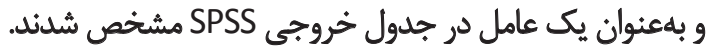

برخلاف تحليل عاملى معمولى، در تحليل عاملى كيو نمي توتوان

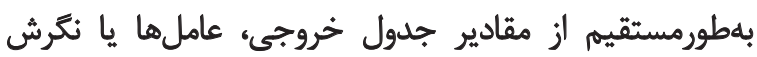

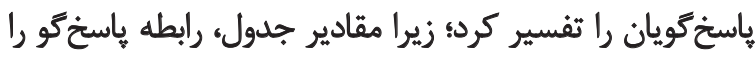

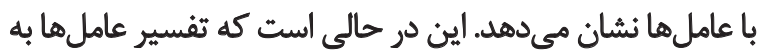

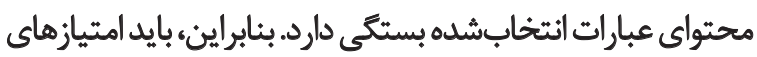

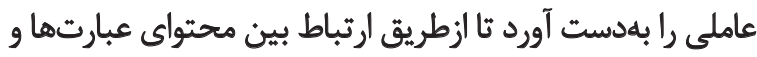

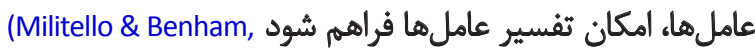

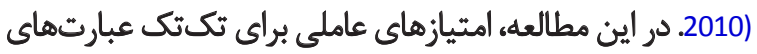

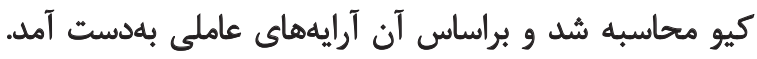

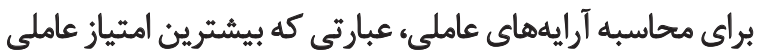

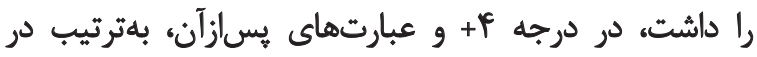

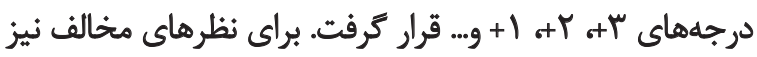

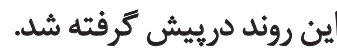

يافتهها

براساس ثتايج بهدستآمده از تحليل عاملى كيو، كارشناسان

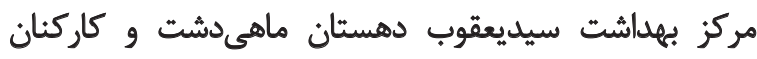

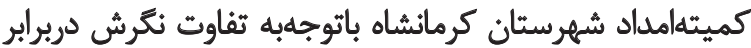

ايجاد دسثة كيو"

هريك از كزارههايى كه در مرحله دوم بلدست آمدانه

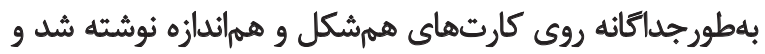

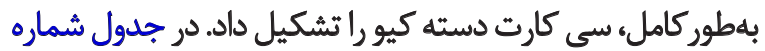
r، كزارههاى مرتبط آورده شده است.

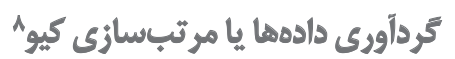

در روش كيو، مرتبسازى به دو شيوه اجبارى و اختيارى

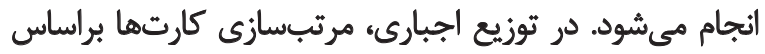

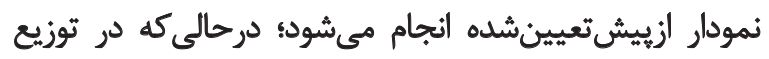

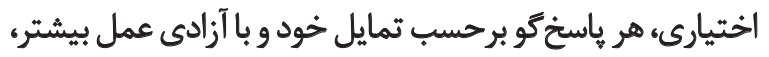

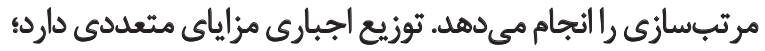

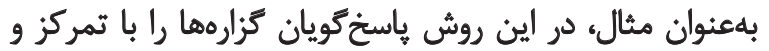

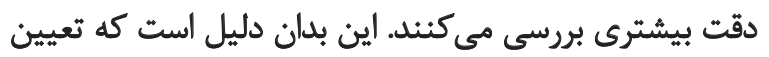

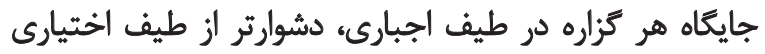

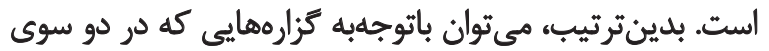

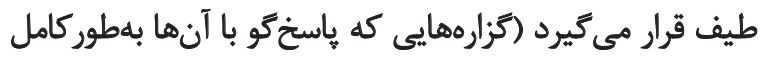

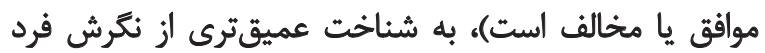

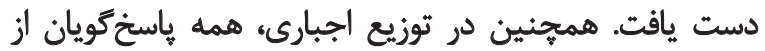

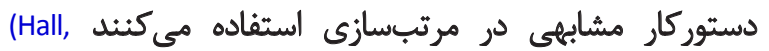

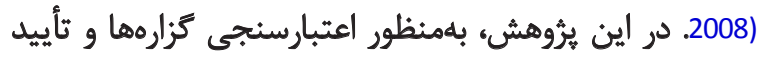

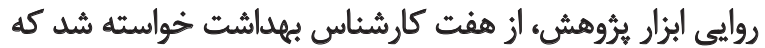

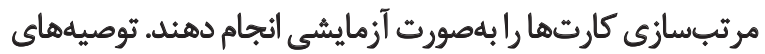

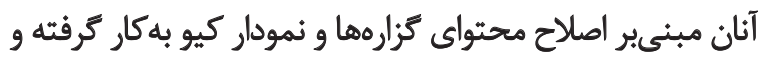

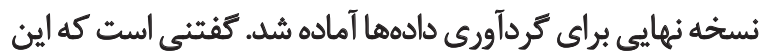

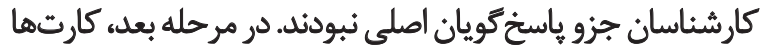

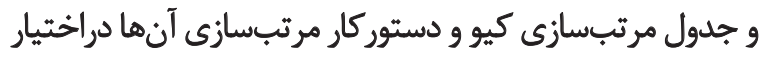

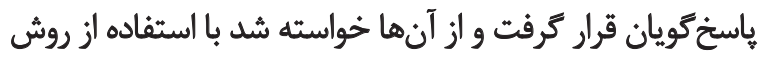


جدول ". عامل هاى استخراجشده از تحليل عاملى كيو

\begin{tabular}{|c|c|c|c|}
\hline درصد واريانس تجمعى & واريانس & مقدار ويزوه & 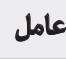 \\
\hline WNT & WNq & r/ap & 1 \\
\hline $\mathrm{me} / \Delta$ & $18 / 1 \mathrm{~V}$ & $T / \Delta A$ & $r$ \\
\hline PNAY & Ir/ge & $r / \pi r$ & $r$ \\
\hline $81 / 10$ & ITIET & $r / . r$ & $f$ \\
\hline$v+/ f+$ & q/Tr & $1 / 4 \lambda$ & $\Delta$ \\
\hline
\end{tabular}

\section{Fingsing}

شده، در تحليل عاملى كيو بهجاى متغيرها، عقيدها و نظرهاي

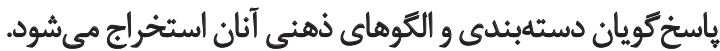

\section{بحث و نتيجه كيرى}

در روششناسى كيو، براى نشاندادن مهمترين عاملها ازنظر

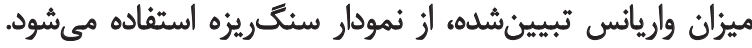

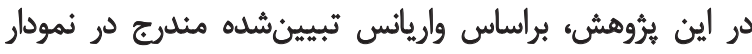

مزايا و معايب كار كودكان روستايى در فعاليتهاى كشاورزى، در

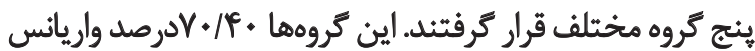

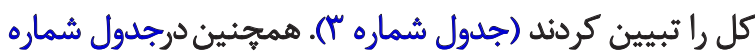

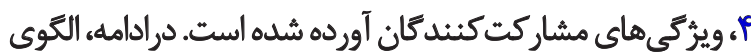
ذهنى كارشناسان در قالب كروههاى ينج كانه تفنسير شد. در جدول ماتريس عاملهها (جدول شماره ه)، دامنه ايدههاى

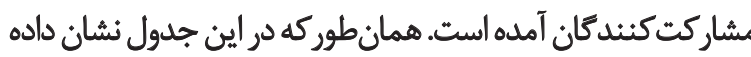

\begin{tabular}{|c|c|c|c|c|}
\hline نهاد محل خدمت & تحصيلات & جنسيت & سن & مشاركت مكندكان \\
\hline مركز بهباشت سيديعقوب ماهى دشت & 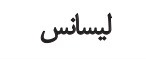 & مرد & il & 1 \\
\hline كميتهامداد استان كرمانشاه & ل ليسانس & 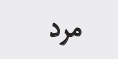 & f. & r \\
\hline مركز بهداشت سيديعقوب ماهى ششت & ل ليسانس & 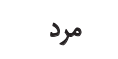 & er & r \\
\hline كميتهامداد استان كرمانشاه & فوقليسانس & 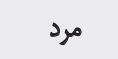 & pr & r \\
\hline كميثلهامداد استان كرمانشاه & ل ليسائس & هرد & i) & $\Delta$ \\
\hline مركز بهاشت سيديعقوب ماهىدشت & فوقليسائس & 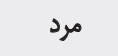 & ra & 8 \\
\hline كميتهامهاد استان كرمانشاه & ل ليسائس & ن & r. & $v$ \\
\hline كميتهامداد استان كرمانشاه & دييلم & مرد & ar & $\wedge$ \\
\hline كميتهامداد استان كرمانشاه & فوقدييلم & 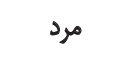 & $m$ & 9 \\
\hline مركز بهداشت سيديعقوب ماهىدشت & 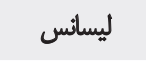 & 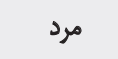 & ru & 1. \\
\hline مركز بهاناشت سيديعقوب ماهىدشت & 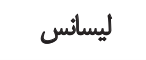 & 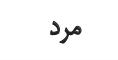 & $r f$ & 11 \\
\hline مركز بهباشت سيديعقوب ماهى دشت & ل ليسانس & 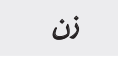 & r & ir \\
\hline مركز بهداشت سيديعقوب ماهى دشت & دييله & 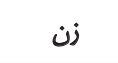 & il & r \\
\hline كميتهامداد استان كرمانشاه & فوقدييلم & ز & r & lif \\
\hline كميثةامداد استان كرمانشاه & فوقدييلم & زن & r. & 10 \\
\hline مركز بهلاثتت سيديعقوب ماهى دشت & ليسانس & زن & re & 18 \\
\hline
\end{tabular}

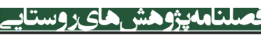


جدول ه. ماتريس همبسئكى ديدكاه اقراد در هريك از الكوهاي ذهنى

\begin{tabular}{|c|c|c|c|c|c|}
\hline \multicolumn{5}{|c|}{ الكوهاى ذهنبى } & \multirow{2}{*}{ مشاركت كثندكان } \\
\hline$\Delta$ & $f$ & $r$ & $r$ & 1 & \\
\hline & & & & $-.10 \cdot 9$ & مشاركت كنتده ششمم \\
\hline & & & & . lAme & هشار كت كننده دوازدهـم \\
\hline & & & & .leme & هشاركت كننده سيزدهم \\
\hline & & & & $\cdot / A V^{\circ}$ & مشاركت كنتلده جهاردهم \\
\hline & & & &.$- / 8 a r$ & مشاركت كنئلها يائزدهـ \\
\hline & & &.$/ 94 \Delta$ & & مشاركت كننده اول \\
\hline & & &.$/ 94 \Delta$ & & مشاركت كننده ينجم \\
\hline & & •MIT & & & مشاركت كتنده سوم \\
\hline & & $+/ \mathrm{VA}$ & & & مشاركت كنتده دهم \\
\hline & & $+|94|$ & & & مشاركت كننده شانزدهم \\
\hline &.$|A D|$ & & & & هشاركت كنثله هفتم \\
\hline & - IEAY & & & & هشاركت كنتنه هشتم \\
\hline & . late & & & & مشاركت كنئده يازدهمه \\
\hline .lamp & & & & & هشاركت كننده جهارم \\
\hline$\cdot / 1 \cdot P$ & & & & & هشاركت كننده نهم \\
\hline
\end{tabular}

\section{في}

موافق بودند؛ زيرا آنان معتقد بودند كه قرارداشتن كودكان

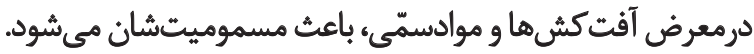

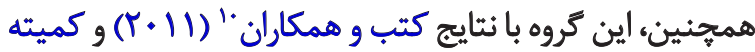

10. Kotb et al.

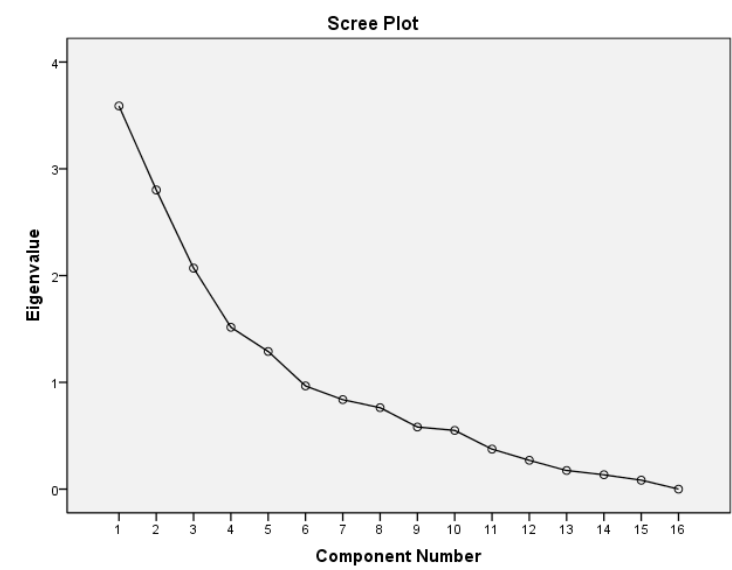

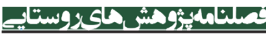

سنگ ريزه، بنج الكوى ذهنى مختلف استخراج شد (تصوير شماره r): ا. الكوى ذهنى اول: اين كروه شامل ينج نفر از شركت كنيندكان

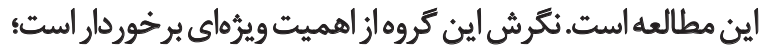

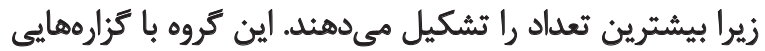

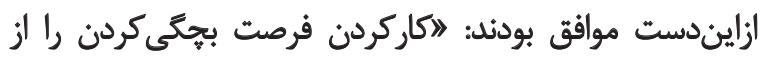

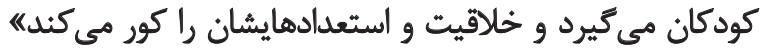

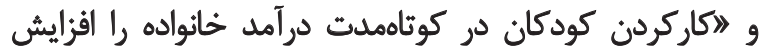

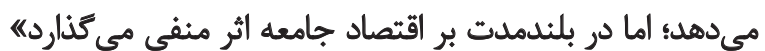

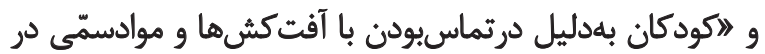

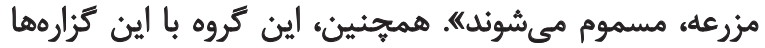

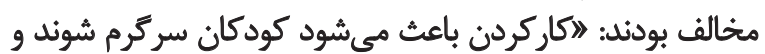

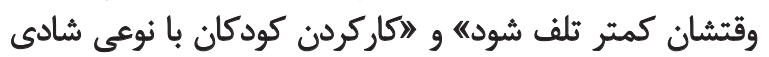

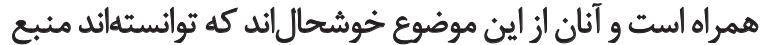

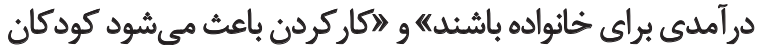

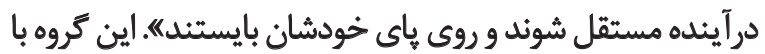

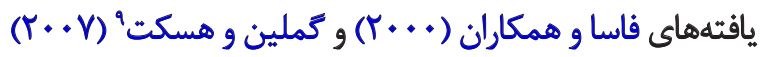

9.Gamlin \& Hesketh 


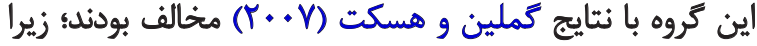

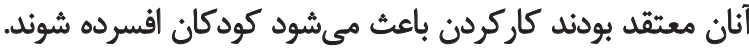

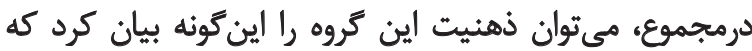

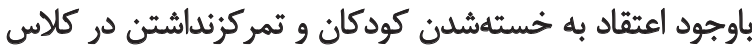

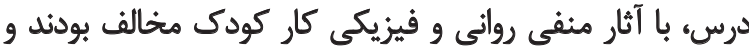

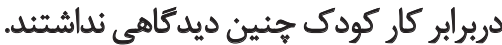

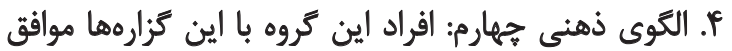

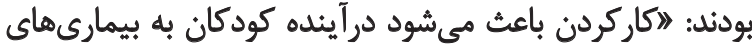

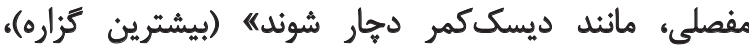

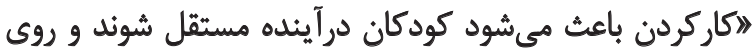

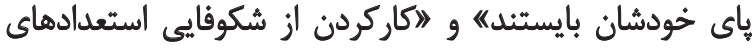

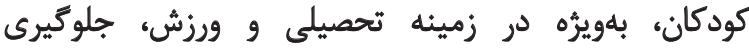

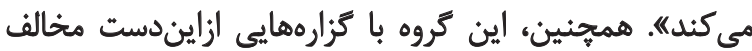

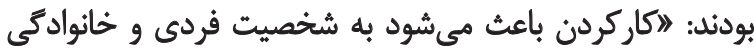

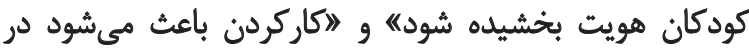

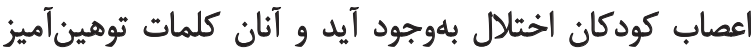

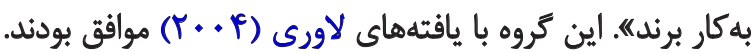

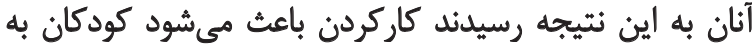

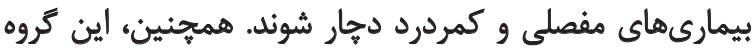
با نتايج كميته بهداشت و ايمنى كار كودكان (1991) موافق

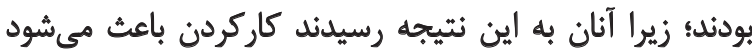

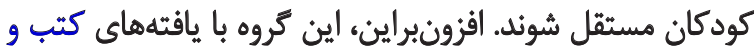

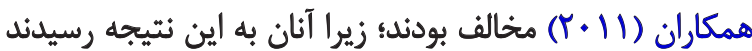

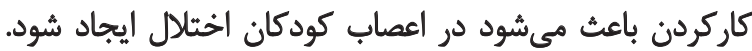

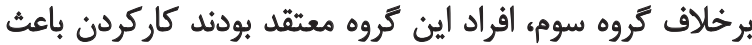

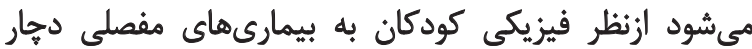

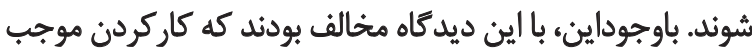

بيمارىهاى روانى، مانند اختلال در اعصاب كودكان مي بشودان.

هـ القوى ذهنى ينجم: افراد اين كروه با كزارههاييى ازايندست

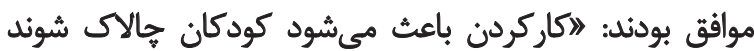

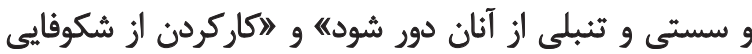

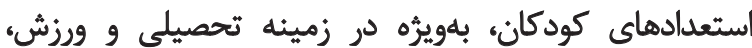

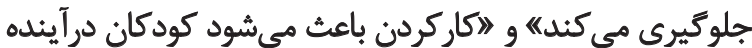

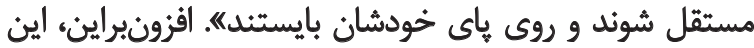

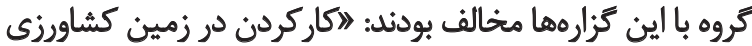

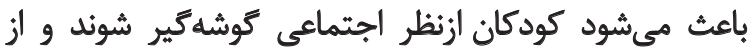

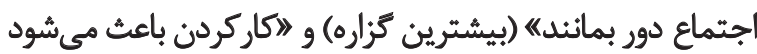

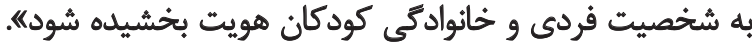
اين تروه با نتايج كميته بهداشت و ايمنى كار كودكان كان كان (1991)

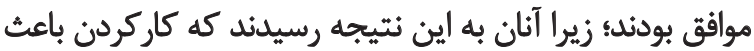

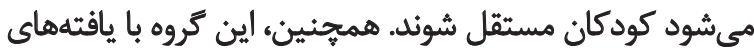

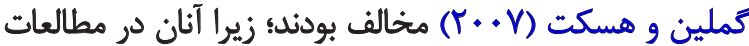
خود به اين نتيجه رسيدند كه كاركردن باعث مي مشود كودكان
أبهداشت و ايمني كار كودكان (1991) مخالف بودندئ هراكه

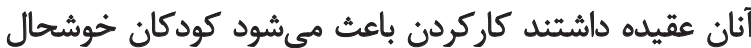

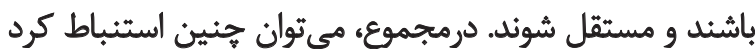

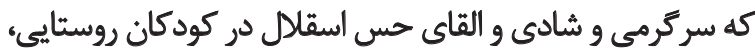

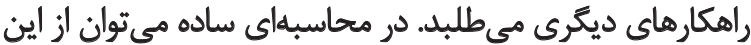

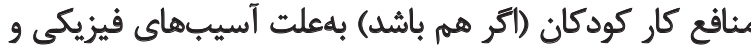

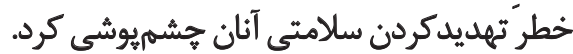

r. الكوى ذهنى دوم: اين گروه با اين گزارهها موافق بودندئ

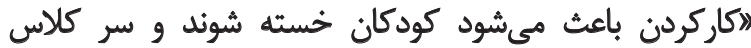

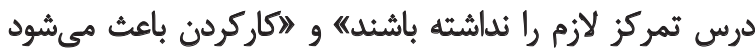

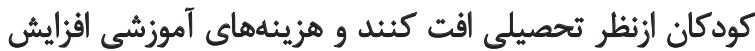

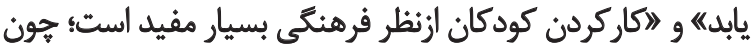

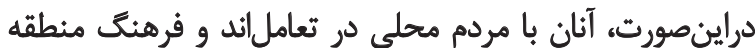

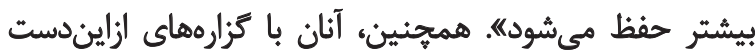

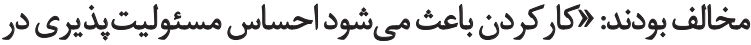

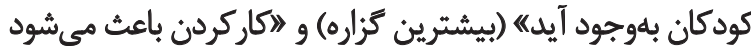

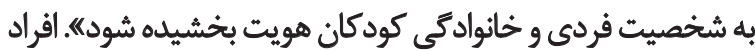

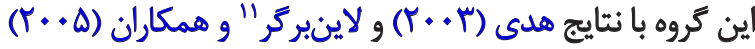

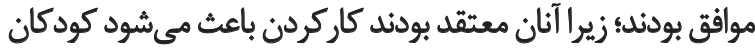

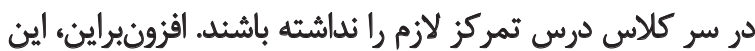

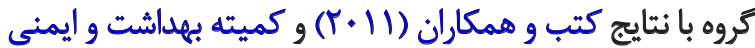
كار كودكان (1991) مخالف بودئن

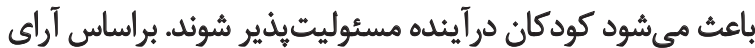

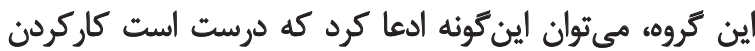

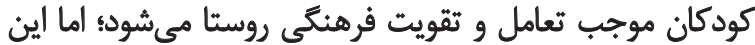

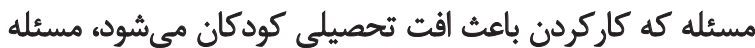
بسيار مهمى است كه بايد مدنظر قرار كيرد.

ب. الكوى ذهنى سوم: اين كروه با كزارههايى ازايندست موافق

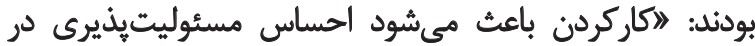

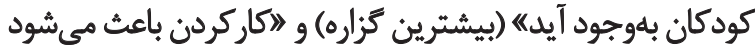

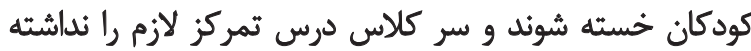

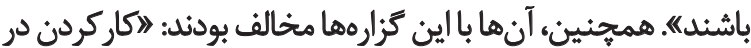

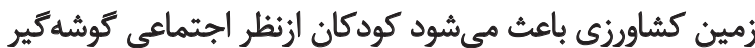

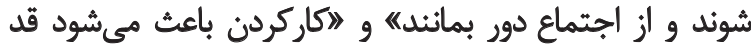

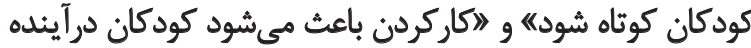

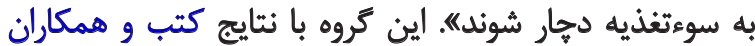

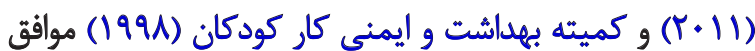
بودند؛ زيرا آنان معتقد بودند كاركاند

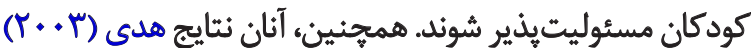

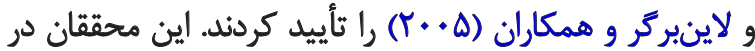

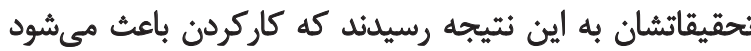
كودكان در كلاس تمركز لازم را نداشته باشنان كاركردن باعث افزونبراين،

11. Leinberger-Jabari et al. 
اففرده شوند. درمجموع، مي توان جنين استئباط كرد كه افراد

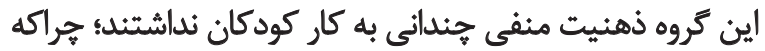
براساس يافتههاي تحقيق، اين يُيشنهادها ارائه ميشود: ا. كاركردن كودى فرصت بهكى را از او مى ئيرد و استعدادهاى

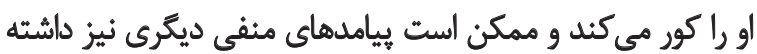

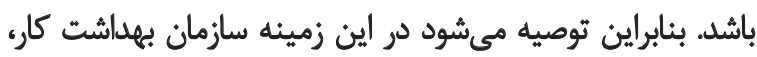

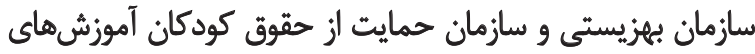

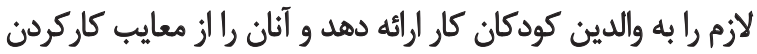

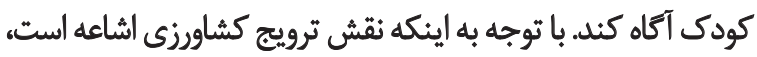

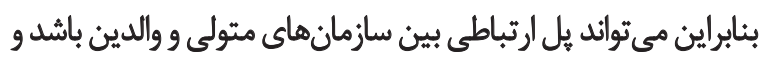
آهوزش هاي لازم را باه والدين بلدهد.

ז. كودكان آيندهازان اين مرزوبوم هستند و بهارئيرى آنان

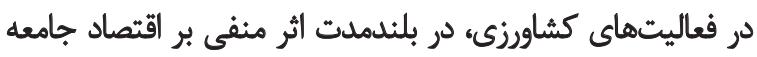

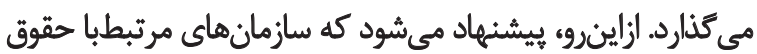

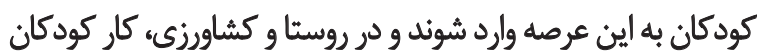
رازيزنظر بكيرند.

". باتوجهبه مشكلات جسمي و روحي كه كودكان كار در كارهاي

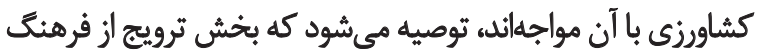
كودكآزارى جلوكيرى كند و به خود كودكان درباره نحوه صحيح

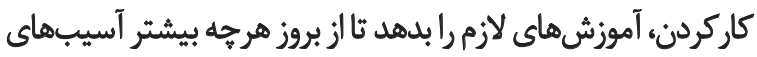
ناشى از كار جلوكيرى شود.

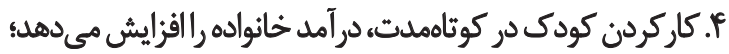

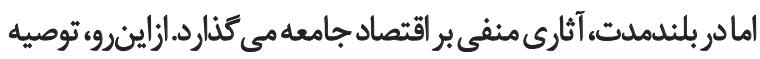

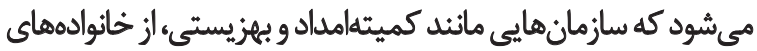

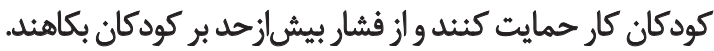

$$
\text { ثึ }
$$

اين معاله بركرفته از ياياننامه دوره كارشناسى ارشد خانم

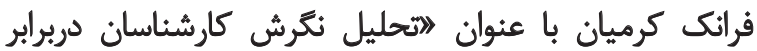

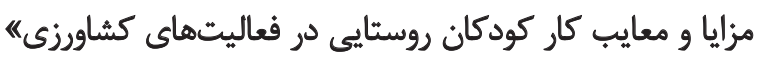

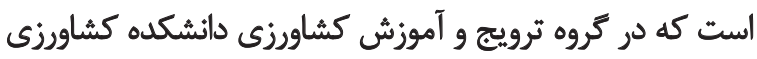

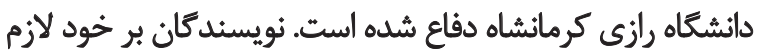

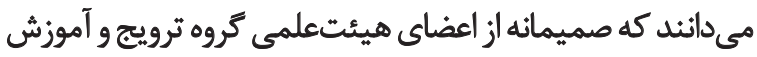

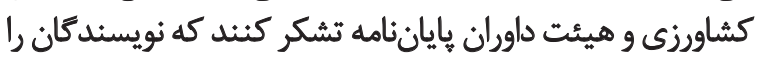

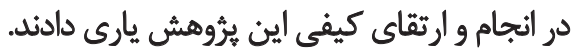

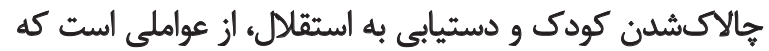

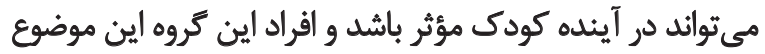
را مهرم ثلقى كرنئ.

مزايا و معايب و بهطوركلى بديده كار كودكان، اشتراك هائي

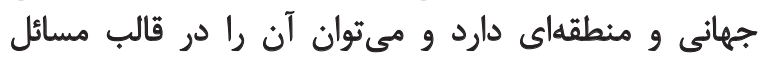

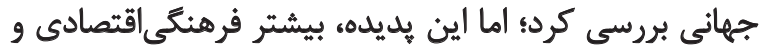

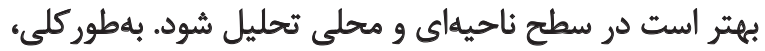

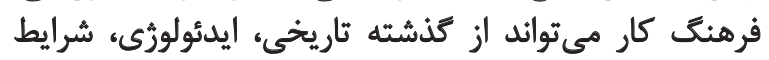

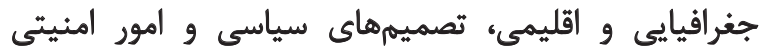

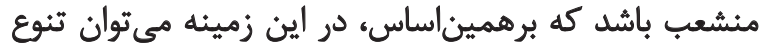

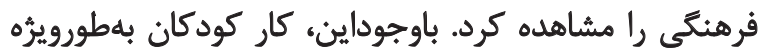

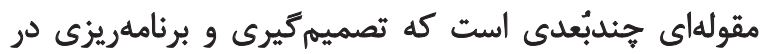

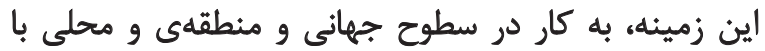
همكارى نهادى مشترى نياز دارد. بيديده كار كودكان در محيطهاى روستايى با ماهيت

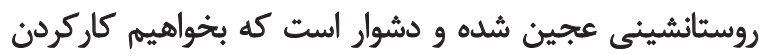

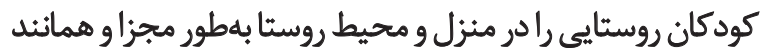

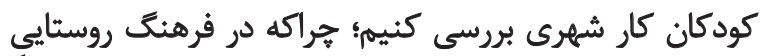

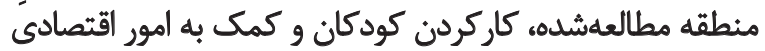

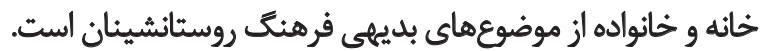

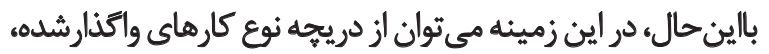

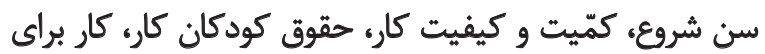

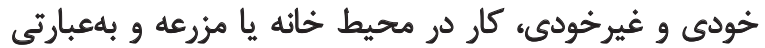

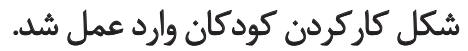

اين امر كه باطوركلى كار كودكان در مزرعه شناخته شود،

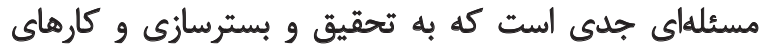

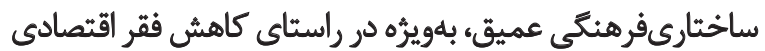

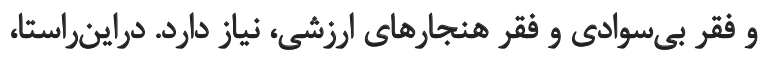

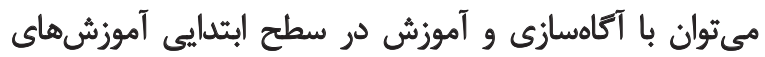

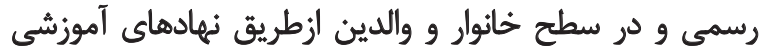

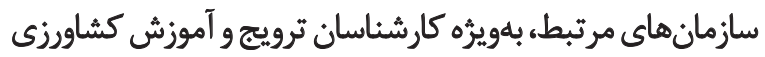

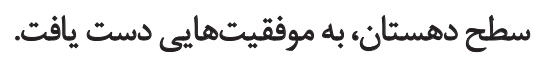

درمجموع، مى توان اين كونه بيان كرد كه از ديدكاه كارشناسان،

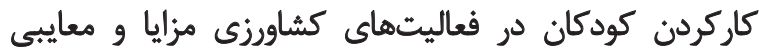

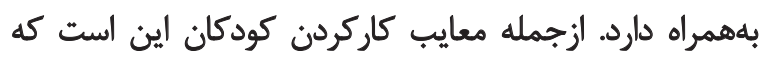

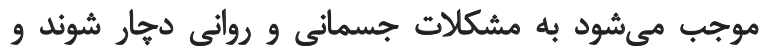

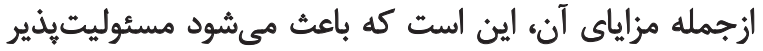

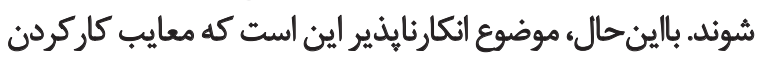
كودكان بيشتر از مزاياى آن جلوه مينمايندائ. 


\section{References}

Akarro, R. R., \& Mtweve, N. A. (2011). Poverty and its association with child labour in Njombe District in Tanzania: The case of Igima Ward. Current Research Journal of Social Sciences, 3(3), 199-206.

Artyaeei, F., Chizari, M., Jafari, M. (2011). [Factors affecting of participation rural youth in agricultural development (Case study: Kermanshah city) (Persian)]. Journal of Rural Research, 2(3), 55-73.

Astinfeshan, S., Alibaygi, A. H., Gholami, M. (2012). [Effect of attachment and satisfaction levels of rural life in Kermanshah City, rural youth participation in agricultural activities (Persian)]. Journal of Rural Research, 6(2), 411-32.

Banerjee, S. R. (1993). Agricultural child labor in West Bengal. Indian pediatrics, 30(12), 1425-9. PubMed: 8077032

Çolak, Ö. F. (2004). Globalization and child work force. Çoluk Çocuk Journal, 4, 31-4

Cruz, R. H. (2002). National report on the results of the child labor survey in Honduras. Geneva: International Labor Organization.

Edet, G. E., \& Etim, N. A. A. (2013). Child labour in agriculture among poor rural households: Some issues and facts. European Journal of Physical and Agricultural Sciences, 1(1), 1-7.

Fassa, A. G., Facchini, L. A., Dall'Agnol, M. M., \& Christiani, D. C. (2000). Child labor and health: Problems and perspectives. International Journal of Occupational and Environmental Health, 6(1), 55-62. doi: 10.1179 /oeh.2000.6.1.55

Food and Agriculture Organization of the United Nation. (2006). World agriculture towards 2030-2050. Rome: Food and Agriculture Organization.

Forastieri, V. (2002). Children at work: Health and safety risks. Genève: International Labour Organization.

Gamlin, J., \& Hesketh, T. (2007). Child work in agriculture: Acute and chronic health hazards. Children Youth and Environments, $17(4), 1-23$.

Hall, C. (2008). Identifying farmer attitudes towards Genetically Modified (GM) crops in Scotland: Are they pro- or anti-GM. Geoforum, 39(1), 204-12. doi: 10.1016/j.geoforum.2007.06.003

Heady, C. (2003). The effect of child labor on learning achievement. World Development, 31(2), 385-98. doi: 10.1016/s0305750x(02)00186-9

International Labor Organization .(2015). World report on child labour: Paving the way to decent work for young people. Geneva: International Labor Organization.

International Labor Organization, \& International Programme on the Elimination of Child Labour. (2007). World day against child labour: Child labour and agriculture. Geneva: International Labor Organization.

International Labor Organization. (2010). Accelerating action against child labour. Geneva: International Labor Organization.

International Labor Organization. (2011). Agriculture: An engine of pro-poor rural growth. Geneva: International Labor Organization.

International Labour Organization. (2006). Tackling hazardous child labour in agriculture guidance on policy and practice. Geneva: International Labor Organization.
Kalantari, S., Kiani, M. (2005). [A comparative study of child labor in developed countries and developing world (Persian)]. Political E Economic Ettelaat, 232, 282-95.

Kotb, S. A., Mohamed, A. G., Abdel Khalek, E. M., \& Yones, D. A. (2011). Agricultural labor among school children in rural Assiut, Egypt. Life Science Journal, 8(2), 423-39.

Leinberger-Jabari, A., Parker, D. L., \& Oberg, C. (2005). Child labor, gender, and health. Public Health Reports, 120(6), 642-7. doi $10.1177 / 003335490512000612$

Lowry, C. (2004). Children's contribution to working and caring for the land: The links between agriculture and children's rights. Canada: $\mathrm{Ca}-$ nadian International Development Agency.

Militello, M., \& Benham, M. K. P. (2010). "Sorting out" collective leadership: How Q-methodology can be used to evaluate leadership development. The Leadership Quarterly, 21(4), 620-32. doi 10.1016/j.leaqua.2010.06.005

Mull, L. D., \& Kirkhorn, S. R. (2005). Child labor in Ghana cocoa production: Focus upon agricultural tasks, ergonomic exposures, and associated injuries and illnesses. Public Health Reports, 120(6), 649-55. doi: 10.1177/003335490512000613

National Research Council. (1998). Protecting youth at work: Health safety, and development of working children and adolescents in the United States. Washington, D.C.: National Academies Press.

Papzan, A., Babaei, M. H., Rezaei, A. (2012). [Analysis of attitude experts technical services consulting towards the concept of sustainable agriculture: Using $Q$ (Persian)]. Paper presented at the $4^{\text {th }}$ Congress of Agricultural Extension and Education and Natural Resources of Iran, Karaj, Iran, 22 August 2012.

Rosati, F. C., \& Straub, R. (2004). Does work during childhood affect adult's health? An analysis for Guatemala. SSRN Electronic Journal. doi: $10.2139 /$ ssrn. 1780263

UNICEF. (2004). The state of world children 2005: Childhood under threat. Retrieved from https://www.unicef.org/publications/ index_24432.htm

Van Exel, J., \& De Graaf, G. (2005). Q methodology: A sneak preview. Retrieved from https://www.researchgate.net/profile/Gjalt Graaf/publication/228574836_Q_Methodology_A_Sneak_Preview/links/02bfe50f946fc9978b000000.pdf

Wilk, V. A. (1993). Health hazards to children in agriculture. American Journal of Industrial Medicine, 24(3), 283-90. doi: 10.1002/ ajim.4700240305 